\title{
Estimation of The Genetic Parameters of Eight Soybean Varieties in The Wasegi Village at Prafi District, Manokwari Regency
}

\author{
Nouke L. Mawikere ${ }^{1}$, Purbokurniawan ${ }^{2}$, Alce Ilona Noya ${ }^{1}$, and Darius Dare ${ }^{2}$ \\ ${ }^{1}$ Postgraduate Program, Department of Agricultural Science, Papua University, Manokwari, Indonesia \\ ${ }^{2}$ Department of Crop Science, Faculty of Agriculture, Papua University, Manokwari, Indonesia
}

Article Info

\section{Received:}

05 February 2020

Accepted:

29 February 2020

Published:

29 February 2020

\section{Competing Interest:}

The authors have declared that no competing interest exists.

\section{Corresponding Author:}

Nouke L. Mawikere, Program, Department of Agricultural Science, Papua University, Manokwari, Indonesia

Email:lenda_mawikere@yahoo.com

(C) 2020 The Authors. This is an open access article under the CC BY license.

\begin{abstract}
In plant breeding programs to select superior varieties that are widely adapted, it can be done with a selection method that is by estimating the value of genetic parameters and the closeness of the relationship between characters. This study aims to estimate genetic parameters including genetic diversity coefficient, phenotypic diversity coefficient, heritability value, and a correlation between the character of plants from eight soybean varieties at Prafi District. The study was designed using a Randomized Block Design (RBD) with 8 treatments of soybean varieties. Each treatment was repeated 4 times, to obtain 32 experimental units. The observed variables included growth and yield components of the eight soybean varieties. The data obtained were analyzed using ANOVA and the significant effect was further tested using the Duncan Multiple Range Test (DMRT) at the 95\% level, through the Costat program. The results of ANOVA analysis were used to obtain the values of genetic parameters including Genetic Diversity Coefficient (GDC), Phenotype Diversity Coefficient (PDC), and Heritability. Correlations between characters were also analyzed using the Costat program. The estimation results of genetic parameters indicate that the characters selected for selection criteria are based on the value of GDC, PDC, and high heritability are the number of branches, number of fertile nodes, number of filled pods, and number of total pods. The characters that show a positive correlation with the yielding character are plant height, number of trifoliate leaves, harvest age, number of filled pods, number of empty pods, total pods, and number of seeds per plant.
\end{abstract}

Keywords: Genetic parameters, Heritability, GDC, PDC, Correlation 


\section{Introduction}

Soybean production in Manokwari Regency, West Papua Province is still low compared to national production. The average soybean production in Manokwari Regency in 2017 was 221 tons/ha, while the national production reached 963,183 tons/ha (BPS, 2018). The low productivity of soybeans influenced by genetic and environmental factors (Yuda et al., 2015). These two factors are often interacting and reflected in agronomic traits that produce highs and lows of yields. Genetic factors can be changed by using superior varieties (Umarie and Holil, 2016).

Based on data from the Directorate General of Food Crops, the Ministry of Agriculture until 2017 has released as many as 92 varieties of soybeans with high yields. The superiority of the variety has not been tested in several areas, including in Manokwari Regency. These superior varieties have different genetic abilities and are likely to give different phenotypic appearance when planted in different environments.

In the plant breeding program to select superior varieties that are widely adapted, it can be done by the selection method by estimating the value of genetic parameters and the close relationship between characters. Hapsari (2014) states before determining the method and implementation of selection, it is necessary to know the estimated value of genetic parameters. Estimation of genetic parameters in plant breeding must be carried out before the improvement of traits to increase the yield of a plant. Breeders suspect the value of genetic parameters to determine the characters that have good potential and can be passed on to the next generation. The results of calculating the value of genetic parameters can be used as a consideration so that the selection process runs effectively. Genetic parameter values include the variability values of genotype, phenotype, environment, heritability, coefficient of genetic diversity, and the correlation between characters that are closely related to the results (Hapsari, 2014; Yuda et al., 2015).

The selection method can run effectively if it is supported by estimating genetic parameters, one of which is with high heritability values of production characters (Sukyanto, 2015; Hastuti et al., 2016). Heritability of an important character is known, especially to estimate the magnitude of genetic influence on plant growth and development and the selection of an environment suitable for the selection process. Selection can also be done by estimating the correlation coefficient between the components of yield and production (Saputra et al., 2016). Correlation function to determine the closeness of the relationship between characters.

Research on estimating genetic parameters for several high-yielding soybean varieties has been conducted in several places in Manokwari Regency but has not been tested in several other locations including Wasegi Village at Prafi District. Therefore, research about estimated genetic parameters of several national soybean varieties in Wasegi Village at Prafi District is needed.

\section{Materials and Methods}

\section{A. Materials}

The research was conducted in Wasegi Village at Prafi District, Manokwari Regency, with a height of about 50 meters above sea level. The materials used are Manure, Ponska fertilizer, Curacon, Furadan 3G, and Soybean Seeds consisting of 8 varieties, namely Demas I, Anjasmoro, Grobogan, Detam I, Dena I, Burangrang, Tanggamus, and Local Prafi.

\section{B. Methods}

The research was designed using a Randomized Block Design (RBD), with 8 treatments of soybean varieties, which are 7 national varieties and 1 Local Prafi variety. Each treatment was repeated 4 times, to obtain 32 experimental units. The research carried out included land preparation, planting, fertilizing, crop maintenance, harvesting, and drying the cobs. The observed variables included growth and yield components of the eight soybean varieties.

\section{Data Analysis}

Data obtained were analyzed using ANOVA at 95\% level. Results of ANOVA analysis used to get Partition Variety, Genetic Diversity Coefficient (GDC), Phenotype Diversity Coefficient (PDC), and Heritability value. The correlation between characters was analyzed using Costat program. The variant component is presented in Table 1.

$$
\begin{aligned}
& \text { Genetic Variety: } \sigma^{2} g=\frac{M_{2}-M_{1}}{r} \\
& \text { Variety of Environmen: } \sigma^{2} e=M_{1} \\
& \text { Phenotypic Variety: } \sigma^{2} p=\sigma^{2} e+\sigma^{2} g
\end{aligned}
$$

Description:

$\sigma^{2} \mathrm{p}=$ Phenotypic Variety

$\sigma^{2} \mathrm{e}=$ Variety of Environment

$\sigma^{2} \mathrm{~g}=$ Genetic Variety

$\mathrm{M}_{1}=$ square of the error

$\mathrm{M}_{2}=$ the middle square of the variety

$\mathrm{r}=$ number of replications

\section{Genetic Diversity Coefficient}

The Genetic Diversity Coefficient (GDC) is determined by the formula ( Singh \& Chaudhary (1979) :

$$
\text { GDC }=\frac{\sqrt{\sigma^{2} g}}{\mathbb{\mu}} x \mathbf{1 0 0} \%
$$


Table 1. Components analysis variant

\begin{tabular}{lllll}
\hline Source of Variation & Free Degree & Sum of Squares & Middle Square & $\begin{array}{l}\text { Squares of } \\
\text { Expectation }\end{array}$ \\
\hline Cluster & $\mathrm{r}-1$ & $\mathrm{JK}_{3}$ & & \\
Varieties & $\mathrm{v}-1$ & $\mathrm{JK}_{2}$ & $\mathrm{M}_{2}$ & $\sigma^{2} \mathrm{e}-\sigma^{2} \mathrm{~g}$ \\
Error & $(\mathrm{r}-1)(\mathrm{v}-1)$ & $\mathrm{K}_{1}$ & $\mathrm{M}_{1}$ & $\sigma^{2} \mathrm{e}$ \\
\hline
\end{tabular}

Total

Description: GDC = Genetic Diversity
Coefficient
$\sigma^{2} \mathrm{~g}=$ Genetic Variety
$\mu \quad=$ general average

Phenotypic Diversity Coefficient (Singh \& Chaudhary, 1979)

$$
\mathrm{PDC}=\frac{\sqrt{\sigma^{2} p}}{\mu} \times 100 \%
$$

Description: PDC $=$ Phenotypic Diversity Coefficient

$$
\begin{aligned}
& \sigma^{2} \mathrm{p}=\text { Phenotypic Variety } \\
& \mu=\text { general average }
\end{aligned}
$$

Heritability (Syukur et al., 2015):

$\mathrm{H}_{(\mathrm{bs})}=\frac{\sigma^{2} g}{\sigma^{2} p}$

Description: $\quad H_{(\text {bs })}=$ Heritability in a broad sense

$$
\begin{aligned}
\sigma^{2} \mathrm{~g} & =\text { Genetic Variety } \\
\sigma^{2} \mathrm{p} & =\text { Phenotypic Variety }
\end{aligned}
$$

Correlation between characters (Hayati, 2018):

$$
\mathrm{r}_{(\mathrm{xy})}=\frac{\operatorname{cov} X Y}{\sqrt{(\operatorname{var} X)(\operatorname{var} Y)}}
$$

Description:

$$
\begin{aligned}
& \mathrm{r}_{(\mathrm{xy})} \text { : Correlation between variable } \mathrm{x} \text { and } \\
& \text { variable } \mathrm{y} \\
& \operatorname{var} \mathrm{X}: \operatorname{varian} \mathrm{X} \\
& \operatorname{var} \mathrm{y}: \text { varian } \mathrm{Y}
\end{aligned}
$$

cov XY : covarian XYscanner.

\section{Results and Discussion}

\section{A. Coefficient of Genotype and Phenotype Diversity}

Selection criteria based on genetic parameters is one of the steps that are effective in supporting the success of plant breeding programs. Genetic parameters are needed to know the characters that have good potential and are strongly influenced by genetic factors so that they can be used as selection criteria in the early generation. The genetic

parameters that can be used to determine the closeness of the correlation with the results are the coefficient of genetic diversity, the coefficient of phenotypic diversity, heritability, and the correlation between characters (Hapsari, 2014).

Predicted values of variance from various analyzes can be partitioned into the variance of phenotype, environment, and genotype. The analysis showed that genotype variance $\left(\sigma^{2} \mathrm{~g}\right)$ of the characters of the observed range between 0,008 to 15,691 and the range of genetic diversity coefficient (GDC) is low to high, ie between $3,91 \%$ to $55,58 \%$. The value of the phenotypic diversity coefficient (FDC) varies from low to high, which is between $9,41 \%$ to 99,08\% ( Table 2).

The GDC with low and rather low criteria is classified as a character that has a narrow variability of genetic characters, while characters who have a high enough to high GDC value are categorized as a wide variability of genetic characters (Hartoko, 2005). The results showed that of the 14 plant characters evaluated, 9 characters had narrow genetic variability and 5 characters had extensive genetic variability. Characters that have wide variability can be used as selection criteria. Characters that have extensive genetic variability are the number of branches/plant, number of fertile nodes, seed weight/plant, number of filled pods, and the total number of pods. The characters that have narrow variability are plant height, number of trifoliate leaves, flowering age, harvest age, number of seeds/pod, number of empty seeds/pod, the weight of 100 seeds, seed weight/plot, and seed weight/hectare. This is in linear with research of Rumfabe (2012) in SP I Prafi reported that the plant height, number of fertile nodes, number of seeds/pod, seed weight/plot, and weight of 100 seeds have narrow variability, but the seed weight/plant has low variability.

Warbaal (2014) in the research on yield stability of soybean varieties in West Papua reported that plant height and weight of 100 seeds had wide variability. The difference in the value of diversity is due to different research locations so that there are environmental influences on the appearance of plant phenotypes. 
Table 2. The characteristics of eight soybean varieties

\begin{tabular}{lccccc}
\hline Character & $\sigma^{2} \mathrm{~g}$ & $\sigma^{2} \mathrm{e}$ & $\sigma^{2} \mathrm{p}$ & PDC (\%) & GDC (\%) \\
\hline Plant height & 88,58 & 82,17 & 170,76 & $15,02(\mathrm{RL})$ & $10,82(\mathrm{~L})$ \\
Number of trifoliate leaves & 15,57 & 299,32 & 314,89 & $93,49(\mathrm{H})$ & $20,79(\mathrm{RL})$ \\
Flowering age & 19,42 & 6,11 & 25,53 & $13,81(\mathrm{RL})$ & $12,04(\mathrm{~L})$ \\
Harvest age & 58,24 & 6,67 & 64,92 & $9,41(\mathrm{~L})$ & $8,91(\mathrm{~L})$ \\
Number of branches & 2,11 & 2,05 & 4,16 & $55,03(\mathrm{H})$ & $39,15(\mathrm{HE})$ \\
Number of fertile nodes & 52,03 & 30,80 & 82,83 & $48,75(\mathrm{H})$ & $38,64(\mathrm{HE})$ \\
Number of filled pods & 225,89 & 195,49 & 421,38 & $56,34(\mathrm{H})$ & $41,25(\mathrm{H})$ \\
Number of total pods & 282,66 & 251,53 & 534,19 & $58,06(\mathrm{H})$ & $42,23(\mathrm{H})$ \\
Number of seeds/pod & 0,008 & 0,064 & 0,072 & $11,78(\mathrm{RL})$ & $3,91(\mathrm{~L})$ \\
Number of empty seeds/pod & 0,053 & 0,34 & 0,39 & $37,74(\mathrm{HE})$ & $13,77(\mathrm{RL})$ \\
Seed weight/plant & 70,44 & 332,78 & 403,22 & $81,17(\mathrm{H})$ & $33,93(\mathrm{HE})$ \\
Seed weight/plot & 15,691 & 153,965 & 169,657 & $40,93(\mathrm{H})$ & $12,45(\mathrm{~L})$ \\
Seed weight/hectare & 88,26 & 245,25 & 333,5 & $35,33(\mathrm{HE})$ & $18,17(\mathrm{RL})$ \\
Weight of 100 seeds & 3,06 & 3,24 & $43,11(\mathrm{H})$ & $10,15(\mathrm{~L})$
\end{tabular}

Description : $\sigma^{2} g=$ Genetic Variety; $\sigma^{2} e=$ Variety of Environment; $\sigma^{2} p=$ Phenotypic Variety; PDC $=$ Phenotypic Diversity Coefficient; GDC $=$ Genetic Diversity Coefficient; $L=$ Low; $R L=$ Rather Low; $H=$ high; $H E=H i g h$ Enough. The criteria of $L=0 \%-13,58 \% ; R L=13,59 \%-31,68 \% ; H E=31,69 \%-40,70 \%$; H= 40,71\%-80,74\% (Hartoko, 2005)

The diversity of a character can also be indicated by the low height of the PDC value. Low PDC values indicate the characters tested tend to be similar, while high PDC values indicate that the characters tested are very diverse. The results showed that the similar character of 8 soybean varieties was shown by the character of the harvest age, while the characters that showed high diversity were the number of trifoliate leaves, number of branches, number of fertile nodes, number of filled pods, number of total pods, seed weight/plant, seed weight/plot, and seed weight/hectare.

The character that has extensive genetic variability has opportunities for effective improvement efforts through selection, while at characters that have narrow genetic variability have not been able to be done selectively because their genetic conditions are still homogeneous (Umarie and Holil, 2016). Thus, broad genetic diversity has a greater chance of selecting the best character when compared to characters who have narrow genetic diversity. Hakim and Suyamto (2012) stated that high genetic diversity indicated that the selection to obtain high yielding or early maturing soybean genotypes had considerable opportunities. Sukyanto (2015) states that a narrow genetic range is caused by the dominant environmental influences, such as rainfall. High rainfall will disrupt the vegetative growth of plants, so the genetic potential of each variety cannot function properly. Based on data from the Meteorology and Geophysics Agency of Prafi District, the average monthly rainfall on when research reach $424 \mathrm{~mm}$ with the average number of rainy days as much as 18 days per month. The optimal rainfall in soybean plants ranging from $300-400 \mathrm{~mm}$, mean rainfall when the research is high, thus affecting the growth and development of soybean plants.

\section{B. Value of Heritability}

Heritability value that describes the correlation between a wide variety of genotypes and phenotypes, so it can be seen how much of phenotypes that appear due to the effect of genotype (Syukur et al., 2015). Mendez-Natera et al., (2012) classify the criteria of heritability values into three parts, that is (1) high if the presentation is more than $50 \%$, (2) moderate if the presentation is between $20 \%$ to $50 \%$, and (3) low if the presentation is less than $20 \%$.

The estimated value of heritability in the broad sense $\left(h_{b s)}\right.$ for each character to be evaluated can be seen in Table 3 . The values of heritability characters 
of the observed plant are low $(4,94 \%)$ to high $(89,72 \%)$. The low heritability value was shown by the character of the number of trifoliate leaves $(4,94 \%)$, the number of seeds/pod $(11,00 \%)$, seed weight/plant $(17,47 \%)$, seed weight/plot $(9,25 \%)$, and seed weight/hectare $(5,55 \%)$. Heritability values with moderate criteria are shown by weight of 100 seeds $(26,46 \%)$, while high heritability values are indicated by characters of plant height $(51,88 \%)$, flowering age $(76,05 \%)$, harvest age $(89,72 \%)$, number of branches $(50,62 \%)$, number of fertile nodes $(62,81 \%)$, number of filled pods $(53,61 \%)$, and number of total pods $(52,91 \%)$.

Characters that have high-value $\mathrm{H}_{(\mathrm{bs})}$ to show that the appearance of phenotypic controlled in a manner genetic. Lubis et al., (2014) stated that high heritability has a greater diversity in the population caused by genetic factors. Characters that have high heritability can be used as selection criteria. Yuda et al., (2015) stated that the high value of the heritability of a character indicates that the selection of agronomic characters can begin in the early generation. Therefore, based on heritability, it can be said that the plant height, flowering age, harvesting age, number of branches, number of fertile nodes, number of filled pods, and number of total pods can be used as selection criteria, but the characters which can be made into criteria selection in the early generation only high plants, number of branches, and number of fertile nodes.

The estimated high heritability does not always result in predictions of high genetic progress. Likewise, high heritability values are not always indicated by high genetic diversity values. This inconsistency is caused by the dependence of genetic progress on the differential standard selection $(\mathrm{k})$, the standard deviation of the phenotype ( $\sigma \mathrm{p})$, and predictive value of heritability (Sukyanto, 2015). Therefore that effort selection to get potential characters will more selective if we do some genetic parameters together. Yuda et al., (2015) stated that efforts to select agronomic characters to produce hope genotypes not only saw genetic diversity but other genetic parameters such as heritability and correlation between characters so that selected genotypes were truly superior. The estimated value of heritability is important, because the appearance of the phenotype of a plant is the interaction between genetics and the environment, while the correlation serves to determine the closeness of the relationship between plant characters (Saputra et al., 2016).

If the three genetic parameters above are integrated (the value of GDC, PDC, and $\mathrm{H}_{(\mathrm{bs})}$ ), as an indicator in selecting the evaluated characters, the characters selected for selection are the number of branches, number of fertile nodes, number of filled pods, and number of total pods. This is because these 4 characters have high GDC, PDC, and $\mathrm{H}_{(\mathrm{bs})}$ values. Thus, characters that can make into criteria selection on generation early based on the third parameter, are several branches and number of fertile nodes. Extensive genetic diversity, high heritability, and high genetic progress will provide opportunities for successful selection of observed characters and provide effective selection progress (Sad'yah, 2010).

\section{Correlation Analysis Between Characters}

The correlation analysis functions to see the relation between the characters. The correlation coefficients range from -1 to +1 . If the correlation value gets closer to +1 , it means that an increase in a character will be followed by an increase in the other properties, and getting closer to -1 means that an increase in a character will reduce the other properties. If the correlation coefficient closer to +1 then shown the increasingly close the relation, whereas if a zero correlation coefficient is obtained, there is no correlation between the two characters. As'ari (2014) states that the criteria of the degree of closeness are based on the correlation coefficient, i.e. there is no correlation between the two variables $(0)$, the correlation is very low $(0-0,25)$, medium correlation $(0,25-0,5)$, high correlation $(0,5-0,75)$, very high correlation $(0,75-0,99)$, and perfect correlation $(1,00)$.

Based on the results of the correlation analysis (Table 4) shows that plant height and the number of trifoliate leaves have a positive significant correlation with all observed characters. This means that the higher the plant height and the number of trifoliate leaves, so that the number of fertile nodes, the number of filled pods, the number of seeds/plant, the weight of 100 seeds, the seed weight/plant, the seed weight/plot, and the seed weight/hectare will increase. The number of plant trifoliate leaves also has a positive very significant correlation with harvest age, number of branches, number of fertile nodes, number of filled pods, and number of total pods.

Number of branches has a positive significant and very significant correlation with the number of seeds/pod, seed weight/plant, seed weight/plot, seed weight/hectare, number of fertile nodes, number of pods, and total pods, but have a negative correlation with the number of empty seeds/pod and weight of 100 seeds. The number of fertile nodes has a positive significant and very significant correlation to the number of filled pods, number of total pods, number of seeds/plant, but has a negative correlation with the weight of 100 seeds.

The number of filled pods have a positive significant and very significant correlation with the number of empty seeds, the weight of 100 seeds, the seed weight/plant, the seed weight/plot, the seed weight/hectare, the total pods, and the number of seeds/pod. The number of total pods correlates with the number of seeds, the weight of 100 seeds, the seed weight/plant, the seed weight/plot, the seed weight/hectare, and the number of seeds/pod. 
Table 3. Value of heritability in the broad sense of several characters

\begin{tabular}{|c|c|c|c|}
\hline No & Character & $\mathrm{H}_{\mathrm{bs}}(\%)$ & Criteria \\
\hline 1 & Plant height & 51,88 & High \\
\hline 2 & Number of trifoliate leaves & 4,94 & Low \\
\hline 3 & Flowering age & 76.05 & High \\
\hline 4 & Harvest age & 89,72 & High \\
\hline 5 & Number of branches & 50,62 & High \\
\hline 6 & Number of fertile nodes & 62,81 & High \\
\hline 7 & Number of filled pods & 53,61 & High \\
\hline 8 & Number of total pods & 52,91 & High \\
\hline 9 & Number of seeds/pod & 11,00 & Low \\
\hline 10 & Number of empty seeds/pod & 13,33 & Low \\
\hline 11 & Seed weight/plant & 17,47 & Low \\
\hline 12 & Seed weight/plot & 9,25 & Low \\
\hline 13 & Seed weight/hectare & 5,55 & Low \\
\hline 14 & Weight of 100 seeds & 26,46 & Medium \\
\hline
\end{tabular}

Table 4. Correlation between the plant characters

\begin{tabular}{|c|c|c|c|c|c|c|c|c|c|c|c|c|c|c|}
\hline & $\pi$ & JDT & UB & UP & JC & JBS & JPI & JPT & $J B$ & JBB & $\begin{array}{l}100 \\
\text { seeds }\end{array}$ & BB & BBP & $\mathrm{BB} / \mathrm{Ha}$ \\
\hline & $\times 1$ & $\times 2$ & $\times 3$ & $\times 4$ & $\times 5$ & $\times 6$ & $\times 7$ & $\times 8$ & $\times 9$ & $\times 10$ & $\times 11$ & $\times 12$ & $\times 13$ & $\times 14$ \\
\hline$\times 1$ & 1 & 0.235 & 0.264 & 0.32 & 0.151 & 0.243 & 0.207 & 0.215 & 0.195 & 0.167 & 0.263 & 0.268 & 0.057 & 0.0517 \\
\hline$\times 2$ & & 1 & 0.704 & $0,64^{* *}$ & $0.53^{* *}$ & $0.682^{*-}$ & $0,671^{-\prime}$ & $0.682^{* *}$ & 0.246 & 0.046 & 0.072 & 0.108 & 0.122 & 0.116 \\
\hline$\times 3$ & & & 1 & $0,764^{* *}$ & $0,399^{*}$ & $0,523^{\cdots}$ & $0,435^{*}$ & $0,434^{*}$ & 0,104 & 0,081 & 0,036 & $-0,072$ & 0,106 & 0,109 \\
\hline$x 4$ & & & & 1 & $0.426^{\circ}$ & $0.5416^{*+}$ & $0.442^{*}$ & $0.47^{\circ}$ & 0.193 & 0.312 & 0,168 & 0.1205 & 0.282 & 0.289 \\
\hline$\times 5$ & & & & & 1 & $0.889^{* *}$ & $0,869^{*-}$ & $0,859^{* *}$ & 0.281 & -0.017 & $-0,154$ & 0,021 & 0,1407 & 0.1533 \\
\hline$\times 6$ & & & & & & 1 & $0,905^{*-}$ & $0,9^{*}$ & $0,399^{\circ}$ & 0,173 & $-0,043$ & 0.127 & 0.258 & 0.265 \\
\hline$\times 7$ & & & & & & & 1 & $0.995^{* *}$ & $0.428^{*}$ & 0.109 & 0.0173 & 0.164 & 0.245 & 0.25 \\
\hline$\times 8$ & & & & & & & & 1 & $0,4207^{*}$ & 0,11 & 0,024 & 0,1919 & 0.27 & 0.275 \\
\hline$\times 9$ & & & & & & & & & 1 & $0,4352^{*}$ & 0.258 & 0,333 & 0,142 & 0,136 \\
\hline$\times 10$ & & & & & & & & & & 1 & $-0,053$ & $0,384^{*}$ & 0,3009 & 0,284 \\
\hline$\times 11$ & & & & & & & & & & & 1 & 0.249 & 0.266 & 0,2719 \\
\hline$\times 12$ & & & & & & & & & & & & 1 & $0,4507^{\circ 7}$ & $0,422^{*}$ \\
\hline$\times 13$ & & & & & & & & & & & & & 1 & $0.996^{* *}$ \\
\hline$\times 14$ & & & & & & & & & & & & & & 1 \\
\hline
\end{tabular}

Description: $*=$ significant correlation coefficient $\alpha=5 \% ; * *=$ significant correlation coefficient $\alpha=1 \% ; T T=$ plant height; JDT $=$ number of trifoliate leaves; UB= flowering age; $U P=$ harvest age; $J C=$ number of branches; $J B S=$ number of fertile nodes; $J P I=$ number of filled pods; JPT $=$ number of total pods; $J B=$ number of seeds $/$ pod; JBB = number of pithy seeds $/$ pod; 100 seeds $=$ weight of 100 seeds; $B B=$ seed weight $/$ plant $B B P=$ seed weight $/$ plot; $B B / H a=$ seed weight $/$ hectare. 
Estimation of the correlation between the other character by character used to reveal the level of the relationship between the characters. The progress of selection will be more effective if it is supported by the correlation between a character and the target character, which will accelerate and save costs to get the desired superior varieties. The target character is usually is yield character, likes weight seeds/plot, or weight seeds/hectare. Rosliana et al., (2018) states that the correlation analysis can be used to identify the relationship between yield and quantitative characters. Malik et al., (2007) states that the correlation analysis is a technique that is useful for providing information about the level of relationship between important characteristics of plants and also a good index to predict the response of results with changes in certain characters.

\section{Conclusions}

Based on the results of the study it can be concluded that estimation results of genetic parameters showed that the number of branches/plant, number of fertile nodes, seed weight/ plant, number of filled pods, number of empty pods, and total pods, had a high genetic diversity coefficient (GDC), while the number of trifoliate leaves. branches, number of fertile nodes, number of filled pods, number of empty pods, total pods, seed weight/plant, seed weight/plot, and seed weight/hectare, have a high coefficient phenotype diversity (PDC).

Characters that have high of heritability broad mean values are plant height, flowering age, harvest age, number of branches, number of fertile nodes, number of filled pods, and the total number of pods. Characters chosen for the selection criteria are the number of branches, number of fertile nodes, number of filled pods, and total number of pods because these 4 characters have high GDC, PDC, and heritability values. Characters that show a positive correlation with the yielding character are plant height, number of trifoliate leaves, harvest age, number of filled pods, number of empty pods, total pods, and number of seeds/plant. Characters that show a negative correlation with the yielding character is flowering age.

\section{Acknowledgments}

Thank We would like to thank DRPM Kemenristek DIKTI for funded this research in the National Research Scheme of MP3EI with Contract Number: 089/SP2H /LT/DRPM/V/2017. We also thank PT. Papuamedco Hijau Selaras for allowed research on oil palm plantations.

\section{References}

[1] Aldillah, R. 2015. Proyeksi Produksi dan Konsumsi Kedelai Indonesia. Jurnal Ekonomi Kuantitatif Terapan 8(1): 9-23.

[2] [AMIS] Agricultural Market Information System. 2015. Indonesia-Soybean at a glance. http://www.fao.org. Access in January 5, 2018.
[3] As'ari, N.P. 2014. Proportion Reductionin Error (pre) dalam Mengukur Asosiasi Penggunaan Kontrasepsi Hormonal terhadap Kejadian Hipertensi. Skripsi Fakultas Matematika dan Ilmu Pengetahuan Alam. Universitas Negeri Yogyakarta.

[4] Badan Pusat Statistik DKI Jakarta, 2017. https://jakarta.bps.go.id/news.html. Access in January 5, 2018.

[5] Badan Litbang Pertanian. 2016. Target Nasional Produksi Kedelai 2016 Meningkat. www.litbang.pertanian.go.id/berita/one/2468/. Access in January 5, 2018.

[6] Hakim and Suyamto. 2012. Heritabilitas dan Harapan Kemajuan Genetik Beberapa Karakter Kuantitatif Populasi Galur F4 Kedelai Hasil Persilangan. Pusat Penelitian Pertanian Tanaman Pangan. Bogor.

[7] Hapsari,R.T. 2014. Pendugaan Keragaman Genetik dan Korelasi Antara Komponen Hasil Kacang Hijau Berumur Genjah. Buletin Plasma Nutfah 20(2): 51-58.

[8] Hartoko, D.A. 2005. Penampilan Beberapa Mutan Kedelai (Glycine max (L.) Merril) di Lahan Kering pada Generasi Kedua. Penebar Swadaya. Jakarta.

[9] Lubis, K., S.H. Sutjahjo, M. Syukur, and Trikoesoemaningtyas. 2014. Pendugaan Parameter Genetik dan Seleksi Karakter Morfofisiologi Galur Jagung Introduksi di Lingkungan Tanah Masam. Jurnal Penelitian Pertanian Tanaman Pangan 33(2): 122-128.

[10] Malik, A.M.F., M. Ashraf, A.S. Qureshi, and A. Ghafoor. 2007. Assessment of Genetic Variability, Correlation and Path Analyses for Yield and Its Components in Soybean. Pakistan Journal of Botany. 39(2):405-413.

[11] Nasir, M. 2001. Pengantar Pemuliaan Tanaman. Proyek Penelitian dan Pengabdian pada Masyarakat. Jakarta.

[12] Pinaria, A., A. Baihaki, R. Setiamihardja, and A.A. Deradjat. 1995. Variabilitas Genetik dan Heritabilitas KarakterKarakter Biomasa 53 Genotip Kedelai. Zuriat 6 (2): 88-92.

[13] Rumfambe, A. 2012. Pendugaan Parameter Genetik untuk Penentuan Seleksi Kedelai Berdaya Hasil Tinggi pada Lahan Sawah di SP I Prafi Manokwari. Skripsi, Fakultas Pertanian dan Teknologi Pertanian Universitas Papua.

[14] Sa'dyah, N., T.R. Basoeki, A. Saputra, Firmansyah, and S.D. Utomo. 2010. Parameter Genetik dan Korelasi Karakter Agronomi Kacang Pajang Populasi F4 Persilangan Testa Coklat X Coklat Putih. Jurnal Agrotropika 15(2): 73-77.

[15] Saputra, T.E., M. Barmawi, Ermawati, and N. Sa'dyah. 2016. Korelasi dan Analisis Lintas Komponen-Komponen Hasil Kedelai Famili F6 Hasil Persilangan Wilis X 3570. Jurnal Penelitian Pertanian Terapan 16(1): 54-60.

[16] Sihotang, R.D.S., M. Nawawi, and S.M. Sitompul. 2015. Yield Diversity at 3 Soybean Strains (Glycine max L. Merril) of F3 Generation From Tanggamus $\mathrm{X}$ Anjasmoro, Tanggamus X Argopuro, Tanggamus X uncrossing. Jurnal Produksi Tanaman 3(5): 377-382.

[17] Sudarmadji, R. Mardjono, and H. Sudarmo. 2007. Variasi Genetik, Heritabilitas, dan Korelasi Genotipik Sifat-sifat Penting Tanaman Wijen (Sesamum indicumL.). J. Littri 13(3): 88-92.

[18] Sukyanto. 2015. Pendugaan Parameter Genetik Tanaman Kedelai (Glycine max L. Merril) pada Sistem Pertanaman Monokultur. Fakultas Pertanian Universitas Muhammadiyah. Jember.

[19] Syukur, M., S. Sujiprihati, and R. Yunianti. 2012. Teknik Pemuliaan Tanaman. Jakarta. Penebar Swadaya.

[20] Umarie, I. 2003. Keragaman Genetik dan Heritabilitas Beberapa Sifat Biomas F3 Silang Lingkar pada Tanaman Kedelai. Fakultas Pertanian Universitas Muhammadiyah. Jember.

[21] Warbaal, A. 2014. Stabilitas Hasil Varietas Kedelai Berdaya Hasil Tinggi di Papua Barat. Tesis Program Pasca Sarjana. Universitas Papua Manokwari.

[22] Yuda P.A., I. Umarie, and W. Widiarti. 2015. Pendugaan Parameter Genetik Tanaman Kedelai pada Sistem Pertanaman Tumpang Sari Tebu-Kedelai (Bulai). Agritrop Jurnal Ilmu Pertanian 137-143. 